\title{
Microbial load reduction using modified Solar Conduction Dryer with composite filters
}

\section{Jadhav, P.; Ashokkumar, S.; Nagwekar, N.*}

Department of Chemical Engineering, Institute of Chemical Technology (formerly UDCT),

N. Parekh Road, Matunga (E), Mumbai India-400019

*E-mail of the corresponding author: nupurnagwekar@gmail.com

\begin{abstract}
The present work studies the microbial load reduction in sapota and beet root by three different drying methods i.e. Open Sun Drying (OSD), Solar Conduction Drying (SCD) and a modified SCD with filters (SCDF). Parameters analyzed were water activity, moisture content, drying kinetics, Total Viable Counts, Total Fungal Counts and ash content. It was found that the samples dried in SCDF showed least microbial counts, faster drying times and lower ash content as comparison to OSD. This study shows that SCD and its modification provide a better alternative for low cost drying of fruits and vegetables for quality retention.
\end{abstract}

Keywords: Microbial reduction; SCD Filters; Sapota; Beetroot. 


\section{Introduction}

The global dehydrated food market is being driven by lifestyle changes and dietary choices. An increase in nutritional awareness among the consumers is pushing the industries and researchers to develop novel technologies which will increase the shelf-life of the product without compromising the nutrition and quality. As per APEDA [1], India exported 87,279.99 MT of dried and preserved vegetables worth USD 162.88 Million during 201617. Though large in volume, there is plenty of scope of improvement in the value.

Small and medium scale producers require low cost dryers which are easily adaptable to a variety of agri-produce.[2] In rural India, where agricultural losses are predominant and there is lack of cold storage facilities, Open Sun Drying (OSD) is followed extensively. The advantages of OSD are simplicity and zero equipment cost. The disadvantages are longer duration of drying, microbial contamination, insect infestation and overall quality degradation.[3] To overcome these disadvantages, many models of solar dryers have been developed.[4] Solar Conduction Dryer (SCD), an indigenously developed Indian technology, is being used by 1500 farmers at household level and micro food processing centers. SCD uses all three modes of heat transfer i.e. conduction, natural convection and radiation. It is electricity-free and completely dependent on solar energy.

Sapota (Achrassapota L.) (Family Sapotaceae) commonly known as chiku in India, is an energy rich fruit with high total soluble solids (20-22\%), digestible sugars, protein, fat, fiber and minerals.[5] It is perishable and easily susceptible to microbial contamination due to high moisture content (69.05 - 75.7\%), and sugar content (11.14 - 20.43\%).[6] The fruits are also easily bruised, which leads to wastage.[7] Beetroot (Beta vulgaris) is a root vegetable that belongs to the family of Chenopodiaceae. Beetroot is also characterized by high moisture content, an abundance of nutrients and proximity to soil due to which it forms a favorable habitat for microbial contaminants.

The objective of this study is to analyze effect of different drying methods on the microbial quality of sapota and beet root samples. The three drying methods under study are Open Sun Drying (OSD), Solar Conduction Drying (SCD) and SCD with filters at the air inlet (SCDF). The drying kinetics, moisture content, water activity and ash content of the samples are also analyzed.

\section{Materials and Methods}

\subsection{Sample collection}

$3 \mathrm{Kg}$ of both Sapota and Beetroot each were procured from a local market in Mumbai. After washing and air drying, fresh samples were sliced into pieces of 4-5 mm thickness. A part of it was analyzed directly as fresh sample and the rest was dried using OSD, SCD and 
SCDF. The fresh and dried samples were analyzed for Moisture Content (MC), water activity $\left(\mathrm{a}_{\mathrm{w}}\right)$, Total Viable Count (TVC), Total Fungal Count (TFC) and ash content.

\subsection{Open Sun Drying (OSD)}

Open sun drying was carried out by placing the slices on sheets made up of 12 micron PET (polyethylene terephthalate) +50 micron LDPE (low density polyethylene). The arrangement was covered by a steel mesh to prevent loss of samples to animals and birds.

\subsection{Solar Conduction Dryer (SCD)}

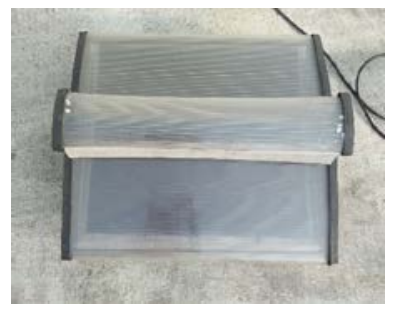

(a)

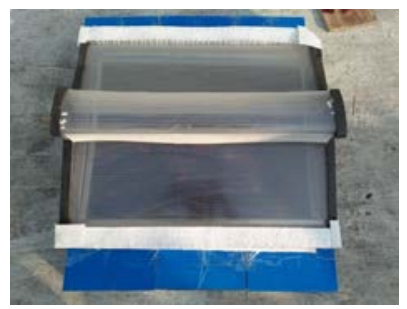

(b)

Fig. 1 (a) Solar Conduction Dryer; (b) Solar Conduction Dryer with Filters

SCD, as shown in Figure 1 (a) (top view) consists of $1 \mathrm{mx} 1 \mathrm{~m}$ tray on which sapota and beetroot slices were loaded and allowed to dry. The surface of the tray provides a temperature of $50-60^{\circ} \mathrm{C}$ with air velocity in the range of $0.1-0.2 \mathrm{~m} / \mathrm{s}$ generated due to natural convection (PCT/IN2012/000843). During the experimental days, the relative humidity of surrounding air was recorded to be $52-60 \%$ at $25-30^{\circ} \mathrm{C}$ (ambient temperature).

\subsection{Solar Conduction Dryer with Filters (SCDF)}

Filter material (Khosla Profil Pvt.Ltd.), is made up of polypropylene with a thickness of $1.35-1.47 \mathrm{~mm}(+/-8 \%)$ and pore size of $0.1 \mu$ with maximum temperature resistance of $80^{\circ} \mathrm{C}$. Filters were placed at both the air inlets of the SCD, as shown in Figure 1 (b) (white coloured filter cloth visible at both open ends of the dryer).

Moisture Content was measured using Shimadzu MOC-120H electronic moisture balance. Water activity $\left(a_{w}\right)$ was measured using a LabSwift Novasina water activity meter. Drying kinetics was studied by measuring the weight of the samples at fixed intervals throughout the drying time to determine the drying rate.

The novel part of SCDF is the use of composite filter attached in such a way so as to provide minimal pressure drop. This is ensured by following ergun type equation.[8]

$$
\frac{\Delta \mathrm{P}}{1 / 2 \rho V^{2}}=\frac{\mathrm{A}}{\mathrm{NRe}} \approx 1
$$


The design of filter is in such a way that there is no kinetic head loss and discharge coefficient (C) derived from the equation 1 takes the following form.

$$
V=C \frac{\sqrt{2 \Delta P}}{\rho}
$$

Where $\mathrm{C}$ is close to 1 .

\subsection{Microbiological Analysis}

The fresh and dried samples of Sapota and Beetroot were subjected to Total Viable Count (TVC) analysis performed by Conventional Plate Count method as recommended by USFDA BAM.[9] Total Fungal Count (TFC) was performed by Pour Plate method as recommended by FSSAI (2012) [10]. The ash analysis was performed as per the method recommended by FSSAI.[11]

\section{Result and discussion}

\subsection{Drying Kinetics}

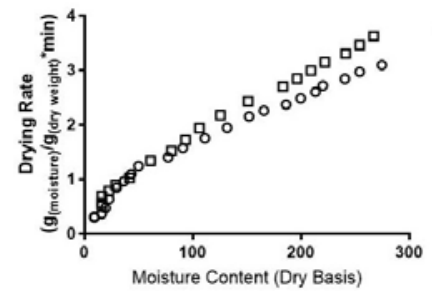

(a)
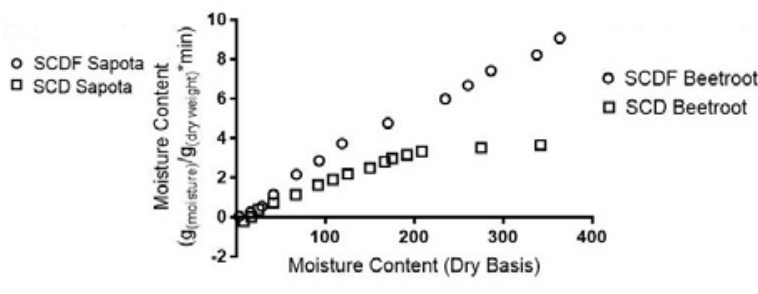

(b)

Fig. 2 (a) Drying Curve for SCD and SCDF Sapota (b) Drying Curve for SCD and SCDF Beetroot

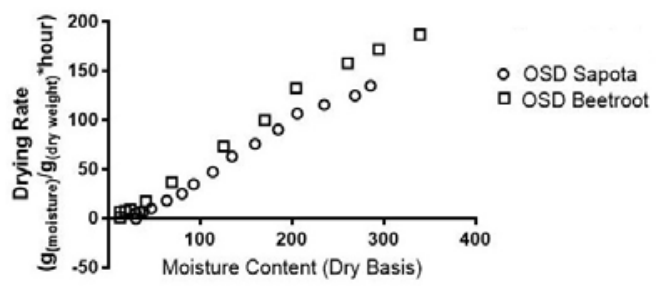

Fig. 3 Drying Curve for OSD Sapota and Beetroot

From Figure 2 and 3 it can be seen that the drying rate of OSD is higher than SCD and SCDF. The time required for drying by SCD and SCDF of Sapota and Beetroot were found to be comparable. Sapota drying required 510 minutes in OSD whereas SCD and SCDF 
required 200 and 240 minutes respectively. For beetroot, the drying times for OSD, SCD and SCDF were 456, 180 and 210 minutes respectively. These values indicate that the drying times in SCD and SCDF are almost half as that of OSD. The drying curves showed a falling-rate period and constant rate period was not observed.[12]

\subsection{Water activity and Moisture Content}

As seen in Table 1, the $\mathrm{a}_{\mathrm{w}}$ of fresh samples of both Sapota and Beetroot was found to be above 0.9. The $a_{w}$ of the OSD was found to be marginally higher than 0.6 , whereas that of SCD and SCDF was found to be well below 0.6. An ANOVA: Single Factor Test revealed significant difference in the means of $\mathrm{a}_{\mathrm{w}}[\mathrm{F}(3,8)=2569.5, \mathrm{p}=1.59 \mathrm{E}-09]$ and $\mathrm{MC}[\mathrm{F}(3,8)$ $=181.5, \mathrm{p}=4.29 \mathrm{E}-06]$ of OSD, SCD and SCDF sapota samples at $5 \%$ level of significance. Significant difference was observed in the means of $\mathrm{a}_{\mathrm{w}}[\mathrm{F}(3,8)=27289.3, \mathrm{p}=1.33 \mathrm{E}-12]$ and MC $[F(3,8)=10.21, p=0.012]$ of OSD, SCD and SCDF beetroot samples. OSD samples showed higher $\mathrm{a}_{\mathrm{w}}$ and MC values as compared to SCD and SCDF. This is due to the temperature difference the food product experiences i.e. $28-30^{\circ} \mathrm{C}$ for OSD and $50-60^{\circ} \mathrm{C}$ for SCD and SCDF leading to higher equilibrium moisture content in OSD samples.

Table 1. Mean \pm SD of Sapota and Beetroot water activity ( $\left.a_{w}\right)$ and \% Moisture (on wet basis)

\begin{tabular}{cccccc}
\hline $\begin{array}{c}\text { Sample } \\
\text { (Sapota) }\end{array}$ & $\begin{array}{c}\text { Water } \\
\text { activity } \\
\left(\mathbf{a}_{\mathbf{w}}\right)\end{array}$ & $\begin{array}{c}\mathbf{\%} \\
\text { Moisture } \\
\mathbf{( w b )}\end{array}$ & $\begin{array}{c}\text { Sample } \\
\text { (Beetroot) }\end{array}$ & $\begin{array}{c}\text { Water } \\
\text { activity (aw) }\end{array}$ & $\begin{array}{c}\% \\
\text { Moisture } \\
\mathbf{( w b )}\end{array}$ \\
\hline Fresh & $0.936 \pm 0.003$ & $69.6 \pm 1.34$ & Fresh & $0.951 \pm 0.001$ & $88.4 \pm 2.61$ \\
OSD & $0.702 \pm 0.009$ & $5.4 \pm 0.35$ & OSD & $0.625 \pm 0.002$ & $12 \pm 2.89$ \\
SCD & $0.341 \pm 0.002$ & $1.2 \pm 0.49$ & SCD & $0.407 \pm 0.002$ & $5.4 \pm 0.98$ \\
SCDF & $0.391 \pm 0.0007$ & $4.8 \pm 0.28$ & SCDF & $0.301 \pm 0.001$ & $6.2 \pm 1.55$ \\
\hline
\end{tabular}

\subsection{Effect of Drying methods on Total Viable Counts (TVC) and Total Fungal Counts (TFC)}

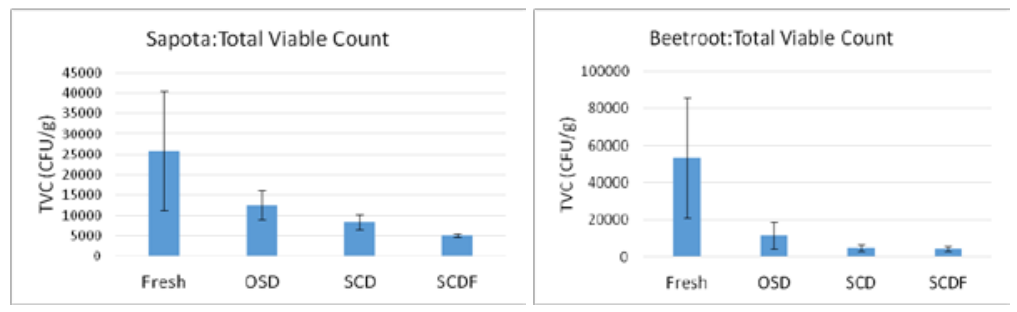

Fig. 4 Total Viable Count of Sapota and Beetroot fresh and dried samples 
The results for TVC and TFC of Sapota and Beetroot are shown in Figure 4 and 5. The comparison of the log reduction in TVC and TFC is given in Table 2. The highest log reduction is found in TVC for SCD and SCDF in beetroot followed by sapota. SCDF performs better in terms of higher log reduction in both sapota and beetroot samples as compared to SCD. Both SCD and SCDF show close to 1 log reduction for TVC counts in beetroot. Previous studies have reported reduction in food microbial counts due to use of thermal drying techniques. Rahman et al. (2000) reported decimal reduction time (time required for $1 \log$ reduction) of 12.66 hrs for drying of Tuna mince at $60^{\circ} \mathrm{C}$ which decreased up to $2.63 \mathrm{hrs}$ as the drying temperature was increased to $100^{\circ} \mathrm{C}$. [13]

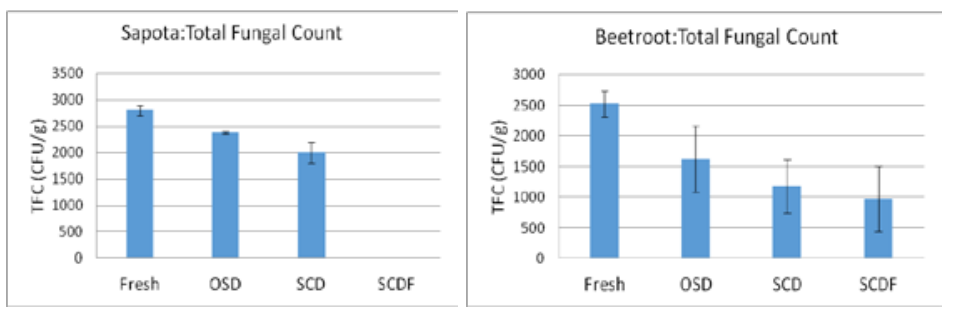

Fig. 5 Total Fungal Count of Sapota and Beetroot fresh and dried samples

Table 2. Comparison of log reduction in the TVC and TFC values of OSD, SCD and SCDF

\begin{tabular}{cccc}
\hline \multirow{2}{*}{ Sample } & $\begin{array}{c}\text { Drying } \\
\text { Method }\end{array}$ & TVC Log reduction & TFC Log reduction \\
\hline \multirow{3}{*}{ Sapota } & OSD & 0.378 & 0.072 \\
& SCD & 0.514 & 0.146 \\
& SCDF & 0.705 & ND \\
Beetroot & OSD & 0.685 & 0.180 \\
& SCD & 1.041 & 0.308 \\
& SCDF & 1.092 & 0.407 \\
\hline
\end{tabular}

\subsection{Ash Content}
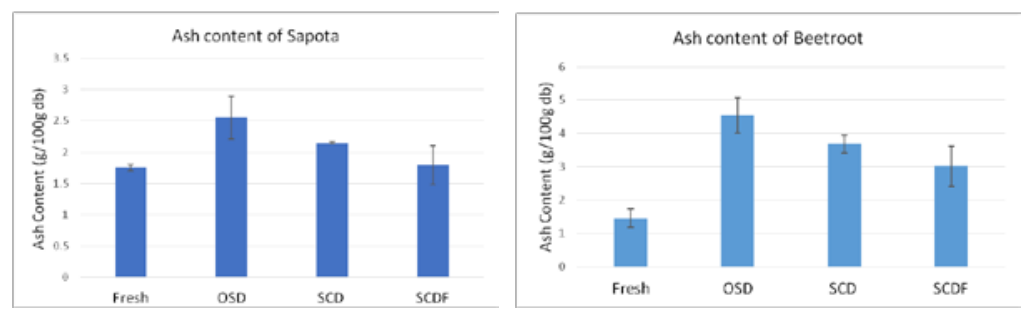

Fig. 6 Ash content (g/100g) (dry basis) in Fresh, OSD, SCD and SCDF samples 
Ash content of a food sample represents the inorganic residue which remains after complete oxidation of the organic matter.[14] All the three drying processes are solar-based, hence ash content helps to measure the inorganic content added in the sample during drying either due to settling of dust, sand or extraneous matter from the environment. As seen in Figure. 6, ash content is highest in OSD samples (completely exposed), followed by SCD (partially covered) and the least in SCDF (filter protected) samples.

\section{Conclusions}

SCD and SCDF showed better product quality with respect to drying time, microbial load reduction and lower ash content as compared to OSD. SCD and SCDF could attain 1 log reduction with a decimal reduction time of 180 mins and 200 mins respectively. The addition of filters to the current design of SCD showed lowered microbial counts as compared to SCD. OSD is currently extensively used by low-income farmers and producer groups. SCD and its modification with filter has the potential to replace open sun drying as a cheap and efficient process without compromising the product safety and quality.

\section{Nomenclature}

\begin{tabular}{|c|c|c|}
\hline OSC & open sun drying & \\
\hline SCD & solar conduction drying & \\
\hline SCDF & $\begin{array}{l}\text { solar conduction drying with } \\
\text { filter }\end{array}$ & \\
\hline TVC & total viable count & \\
\hline TFC & total fungal count & \\
\hline$a_{w}$ & water activity & \\
\hline MC & moisture content & Pascals \\
\hline $\mathrm{P}$ & pressure drop & \\
\hline $\mathrm{V}$ & velocity of air & \\
\hline $\mathrm{NR}_{\mathrm{e}}$ & air flow Reynolds number & \\
\hline A & constant in laminal flow & \\
\hline
\end{tabular}

Greek letters
$\rho$
Density
$\mathrm{Kg} / \mathrm{m}^{3}$

\section{References}

[1] APEDA: Ministry of Commerce \& Industry, Government Of India http://apeda.gov.in/apedawebsite/SubHead_Products/Dried_and_Preserved_Vegetable $\underline{\text { s.htm }}$ 
[2] Tiwari, A. A Review on Solar Drying of Agricultural Produce. In Journal Food Process Technology 2016, 7: 623.

[3] Aravindh, M.A.; Sreekumar, A. Solar Drying-A Sustainable Way of Food Processing. In Energy Sustainability Through Green Energy; Green Energy and Technology; Sharma, A., and Kar, S.K. Ed.; Springer India, 2015; 27-46.

[4] Visavale, G.L. Principles, Classification and Selection of Solar Dryers. Solar drying: Fundamentals, Applications and Innovations; Hii, C.L., Ong, S.P., Jangam, S.V. and Mujumdar, A.S. Eds.; TPR Group.: Singapore, 2012, 1-50.

[5] Suhasini. J.; Kanamadi, V.C.; Swamy, G.S.K.; Shirol, A. M.; Chavan, M. Performance of sapota (Achrassapota L.) varieties and hybrids under Ghataprabha command area. Karnataka Journal of Agricultural Sciences 2011, 25, 548-551.

[6] Morton, J. Sapodilla. Fruits of warm climates; Curtis F. Dowling Ed.; Miami, FL, 1987; 393-398.

[7] Ganjyal G.M.; Hanna M.A.; Devadattam D.S.K. Processing of Sapota (Sapodilla). Powdering. Journal of Food Technolgy 2005, 3(3), 326-330.

[8] Thorat, B. N.; Kataria, K.; Kulkarni, A.V.; Joshi, B. J. Pressure drop studies in bubble column. Journal of the American Chemical Society 2001, 40 (16), 3675-3688.

[9] Maturin, L.; Peeler, J.T.; Aerobic Plate Count. Microbiological Methods \& Bacteriological Analytical Manual (BAM), 8th edition, Revision A. U.S. Food and Drug Administration: Maryland, 1998.

[10] FSSAI; Estimation of Yeast and Mold in Food and Beverages. In Manual of Methods of Analysis of Foods: Microbiological Testing; Food Safety and Standards Authority of India, Ministry of Health and Family Welfare, Government of India [online]: New Delhi, 2012, 45-46.

[11] FSSAI; Estimation of Yeast and Mold in Food and Beverages. In Manual of Methods of Analysis of Foods: Microbiological Testing; Food Safety and Standards Authority of India, Ministry of Health and Family Welfare, Government of India [online]: New Delhi, 2012, 45-46.

[12] Nagwekar, N.; Tidke, V.; Thorat, B.N. Microbial and biochemical analysis of dried fish and comparative study using different drying methods. In Handbook of Drying Technology 2017, 35 (12), 1481-1491.

[13] Rahman, M.S.; Guizani, N.; Al-Ruzeiki, M.; Al Khalasi, A.S. Microflora Changes in Tuna Mince during Convection Air drying. Drying Technology 2000, 18 (10), 23692379.

[14] Marshall, M.R. Ash Analysis. Food Analysis; Heldman.D.R. Ed.; Springer: Boston, MA, 2010; 105-115. 